\title{
QUEIRÓS, Eça de. A correspondência de Fradique Mendes (Memórias e Notas). REIS, Carlos; FIALHO, Irene; SIMÕES, Maria João (Orgs.). Lisboa: Imprensa Nacional/Casa da Moeda, 2014. 436 p.
}

Prosseguindo num ritmo tão regular quanto apreciável, a edição crítica das obras de Eça de Queirós passou recentemente a integrar mais um título, cuja responsabilidade editorial cabe a Carlos Reis (Coordenador do projeto), Irene Fialho e Maria João Simões. Reunindo textos publicados de uma forma "dispersa, no espaço e no tempo", segundo as palavras de Carlos Reis na Nota Prefacial, e surgindo em volume pouco tempo depois da morte de Eça, A Correspondência de Fradique Mendes (Memórias e Notas) constitui um complexo desafio à reposição da definitiva vontade do Autor (se é que se pode falar em definitivo, conhecendo o processo criativo queirosiano), não só quanto ao texto da biografia de Fradique e respetivas cartas, mas também quanto à ordenação destas últimas.

Da complexidade de que falamos dá-nos conta a extensa Introdução que precede o texto crítico, nomeadamente resgatando da história literária queirosiana o arco temporal entre meados da década de 80 e o ano de 1900, período durante o qual a figura de Fradique Mendes vai ganhando as feições que o leitor até hoje lhe reconhece. Com efeito, é em 1885 que Eça escreve a Oliveira Martins, então diretor do jornal portuense A Província, propondo-lhe a publicação de "uma série de cartas sobre toda a sorte de assuntos, desde a imortalidade da alma até ao preço do carvão, escritas por um certo grande homem que viveu aqui há tempos, depois do cerco de Tróia e antes do de Paris, e que se chamava Fradique Mendes! Não te lembras dele?" E acrescentava, um pouco mais à frente, que esta correspondência seria "precedida, está claro, por um estudo sobre a vida e opiniões desse lamentado gentleman". Sem se ter concretizado então, o projeto é retomado em 1888 e novamente proposto ao mesmo Oliveira Martins que, da direção d'A Província, passara entretanto para a d' $O$ Repórter. É assim que, entre agosto de 1888 e outubro do mesmo ano, surgem nas páginas d'O Repórter os primeiros seis capítulos da biografia de Fradique Mendes. A publicação é interrompida pela saída de Oliveira Martins do jornal, mas prossegue na Gazeta de Notícias, do Rio de Janeiro, que, quase em simultâneo, dava ao conhecimento do público brasileiro a figura do mencionado gentleman. Acrescente-se que, por esta altura, já se esboçava, pelo menos, a publicação em livro, conforme é documentado pela correspondência trocada entre Eça de Queirós e os seus editores Lugan e Genelioux. No ano seguinte, quando enfim ganha realidade a Revista de Portugal, Eça não dispensa Fradique, de quem volta a publicar a biografia, bem como algumas das cartas anteriormente publicadas nos periódicos atrás referidos. Desta forma, antes da publicação em volume, o texto ou, nas palavras dos responsáveis por esta edição crítica, o macrotexto de Fradique Mendes contava já, pelo menos, com três impressões apresentando entre si consideráveis divergências. Todas estas questões relativas à tradição impressa d'A Correspondência de Fradique Mendes são minuciosamente tratadas na Introdução, sendo de assinalar os quadros que procedem à comparação dos diferentes testemunhos.

Também os autógrafos são analisados, conferindo o justo relevo a materiais que, para lá do interesse quanto ao conhecimento da oficina do Escritor e ao desafio que comportam relativamente a uma abordagem genética da figura e do mundo fradiquista, se revelam de grande importância nas decisões dos editores relativamente à fixação do texto e ao aparato crítico que o acompanha. São os seguintes esses autógrafos: as seis cartas de Fradique que Eça nunca publicou e que o seu filho, em 1929, deu a conhecer no volume póstumo com o título Cartas Inéditas de Fradique Mendes e mais Páginas Esquecidas; o manuscrito contendo a carta a Eduardo Prado, postumamente publicada por Luís de Magalhães, em 1912, no volume a que deu o título Últimas Páginas; o manuscrito Alberto de Serpa, da Biblioteca Pública Municipal do Porto; o manuscrito Salema Garção, adquirido em 2004, pela Biblioteca Nacional. Quanto a este último, criteriosamente descrito na Introdução do volume que agora nos ocupa, pelo que se evita aqui o que não passaria de uma repetição sem proveito, interessa sobretudo ressaltar a sua localização temporal entre os impressos d'O Repórter e da Gazeta de Notícias e os impressos posteriores, da Revista de Portugal e do volume publicado em 1900. Ou seja, Eça serviu-se dos 
textos já publicados nos dois jornais (o de Lisboa e o do Rio de Janeiro) e sobre eles, emendando e reescrevendo, preparou o texto que, a partir de 1889 , veio a sair na Revista de Portugal. A esta conclusão chegam os editores pelo cotejo entre os diferentes impressos e o manuscrito, profusamente emendado e composto por materiais de diferente natureza: provas tipográficas, recortes de jornal colados sobre folhas de papel e autógrafos, sendo legítimo supor que estes terão surgido sempre que o número e a dimensão das emendas sobre as provas e os recortes de jornal tornavam impossível a leitura. No que se refere ao manuscrito Alberto de Serpa (assim designado por ter pertencido ao poeta), dele fazem parte 124 folhas de provas tipográficas da Revista de Portugal, bem como folhas "visivelmente arrancadas para servirem de ponto de partida para a publicação do livro". E prosseguem os editores: "sobre essas folhas Eça foi acumulando emendas e procedendo a supressões, como que trabalhando sobre uma versão a superar" (p. 54). O que não quer dizer, no entanto, que este texto emendado configure a versão final destinada ao volume: uma anotação - "Precisam-se outras provas" - feita pela mão do Autor, e certamente decorrente da quantidade e vastidão das alterações introduzidas, indicia a existência das referidas "outras provas" com novas alterações. O que leva à conclusão de que "o texto emendado que o Ms. Alberto de Serpa faculta não corresponde ao estado ne varietur, que, para todos os efeitos, continua a ser o de 1900" (p. 55).

Tratando-se de um volume semipóstumo, isto é, um volume cuja revisão final Eça de Queirós não completou, algumas questões se levantam relativamente à salvaguarda da última vontade do Autor: quanto ao texto e, no caso particular de textos dispersos previamente publicados, quanto à respetiva seleção e ordenação. Por outras palavras: até que ponto levou Eça a preparação do volume que durante tantos anos o ocupou? Qual a amplitude das intervenções de quem (supõe-se ter sido Júlio Brandão) levou a cabo a primeira edição, no próprio ano de 1900? Na ausência de documentação que possa, eventualmente, esclarecer as dúvidas assim levantadas, decidiram os editores adotar como texto base o do volume de 1900, dado o facto de as emendas constantes do Ms. Alberto de Serpa não traduzirem ainda a versão final destinada ao volume. Quanto ao aparato crítico, a decisão recai no cotejo com o texto da Revista de Portugal, por considerarem os editores que A Correspondência de Fradique Mendes aí publicada "constitui, para todos os efeitos, o corpus mais extenso e consistente deste complexo e algo fugidio macrotexto queirosiano, antes do aparecimento do livro" (p. 56).

O corpus epistolar selecionado por esta edição não difere do da edição semipóstuma de 1900, acrescido, porém, da última carta a Clara, publicada na Gazeta de Notícias, em 1892. Ficam, pois, de fora as cartas nunca publicadas em vida do Escritor. No entanto, face ao seu interesse no âmbito da mundividência fradiquista, resolveram os editores integrá-las na secção de Apêndices, onde são alvo, tal como as do corpus principal, de uma leitura crítica que adota como texto base o dos manuscritos pertencentes ao espólio de Eça de Queirós, património da Biblioteca Nacional. São estas cartas, recorde-se, as que integram o volume Cartas Inéditas de Eça de Queirós e mais Páginas Esquecidas (1929), bem como a carta a Eduardo Prado, recolhida por Luís de Magalhães no volume Últimas Páginas (1912). Registe-se finalmente que esta mesma secção de Apêndices permite uma revisitação ao chamado "primeiro Fradique", através da leitura de três composições do então poeta satânico Carlos Fradique Mendes.

Muito mais do que aqui foi dito está presente na edição crítica d'A Correspondência de Fradique Mendes (Memórias e Notas), fazendo justiça à modernidade de uma figura que permitiu ao seu criador servir-se de um Outro para pensar o mundo e pensar-se a si mesmo. O longo e ponderado trabalho que esta edição exigiu permite agora redescobrir essa figura e, como instrumento de trabalho, desafia o surgimento de novos olhares sobre "uma das mais fascinantes, complexas e polissémicas obras de Eça de Queirós” (p. 24).

MARIA Do RosÁRIO DA CUNHA DUARTE Universidade Aberta de Lisboa

Recebido: 17 de maio 2014 Aprovado: 02 de outubro 2014 Contato: rosario.duarte@uab.pt 